\title{
ПСИХОЛОГИЧЕСКИЕ И МАРКЕТИНГОВЫЕ СВОЙСТВА Я-КОНЦЕПЦИИ ПОТРЕБИТЕЛЯ
}

\begin{abstract}
Аннотация. Реклама, промоушн, маркетинг всё более и более тонко воздействуют на потенциального покупателя, уже не просто мотивируя его, а вторгаясь в глубинные пласты Я-концепции. Исследование посвящено анализу того, какие особенности Я-концепции отзываются на маркетинговое воздействие. Я-концепция потребителя, по мнению авторов, - это структурный пласт общей Я-концепции, активизирующийся при выборе товара и всегда скреплённый с товаром. Рассмотрены психологические свойства Я-концепции потребителя, т.е. те, которые обеспечивают субъектный контроль покупок: потребительская рефлексивность, осознанность, прогностичность, челеполагание, кризисное проявление, экстериоризация личности, самореализация, терминальность, интернальность, сложность ценностно-мотивационной структуры личности. Также обозначены маркетинговые свойства Я-концепции потребителя, т.е. те, которые обеспечивают активное реагирование на внешнюю стимуляцию продаж и тем самым потребительскую объектность: диадность с товаром, реактивность, сензитивность, зависимость от рекламы и продавиа, психическую пассивность, символизм, пластичность. Определено, что Я-концепция потребителя обладает следующими функциями: регулятивной, ограничивающей, антиманипуляционной, функцией самоопределения в мире вещей, функцией ускорения потребления.

Ключевые слова: экономическая психология, психология потребления, психология потребительского поведения, психология в маркетинге, Я-концепция, Образ Я, субъектность, объектность, психологические свойства Я-концепции, маркетинговые свойства Я-концепции.
\end{abstract}

Review. Advertising, promotion, marketing effect a potential buyer more and more subtly, not just motivating him but invading the deep layers of his self-concept. The present research is dedicated to the analysis of what features of the self-concept respond to the marketing impact. According to the authors, the consumer self-concept is a structural layer of the general self-concept which becomes activated when you use the product and is always bonded with the product. In her article Posypanova has researched psychological features of the consumer selfconcept, in other words, those that provide a subjective control over shopping and buying products: consumer self-analysis and reflection, awareness, predicting ability, goal-setting ability, crisis manifestation, personality externalization, self-realization, terminality, internality and complexity of the personal structure of values and motives. The author has also described marketing features of the consumer self-concept, in other words, those that provide active response to external sales stimulus and thus influence the consumer objectivity: dualism with the goods, reactivity, sensitivity, dependence on advertisements and the seller, mental passivity, symbolism and plasticity. It was determined that the consumer self-concept has the following functions: regulatory, restrictive, antimanipulational functions, the function of self-determination in the world of things and the function of the acceleration of consumption.

Keywords: objectivity, subjectivity, marketing features of self-concept, psychology in marketing, self-concept, selfimage, consumer behavior psychology, consumer psychology, economic psychology, psychological features of selfconcept.

\footnotetext{
Исследование выполнено при финансовой поддержке Российского гуманитарного научного фонда и Правительства Калужской области. Грант № 14-16-40003а(р) «Я-концепция потребителя как условие реакции на манипуляционные техники продаж (на примере молодежи г. Калуги)».
} 
$\prod$ отребительское сознание покупателя высокоразвито, но несубъектно: шопинг уже не просто покупки, но и отдых, общение, снятие стресса, развлечение. Кроме того, молодой покупатель крайне податлив рекламе, убеждениям продавца, акциям и т.п. Если старшее поколение имеет достаточно развитые моральнонравственные устои, душевные и духовные ценности и реагирует главным образом на акции и советы референтной группы, то молодежь - поколение с потребительским мышлением. При таком подходе через несколько лет сформируется поколение, меряющее ценности ценой товара.

Рыночное воздействие на потребителя уже не столь навязчиво и грубо, как было раньше. Реклама, промоушн, маркетинг все более и более тонко воздействуют на потенциального покупателя, уже не просто мотивируя его, а вторгаясь в глубинные пласты Я-концепции.

В связи с этим, цель работы - определение того, благодаря каким особенностям Я-концепция потребителя реагирует на маркетинговые воздействия. Под ними мы в данном случае понимаем любые воздействия, извне стимулирующие покупку того или иного товара.

\section{Теоретический обзор}

Фундаментальной основой исследования стали: концепция отношений в экономической деятельности А.Л. Журавлева, А.Б. Купрейченко [1], концепция ноосферной стадии эволюции социально-экономических систем А.Н. Неверова [2], аналитические труды В.В. Спасенникова [3].

Научным фундаментом исследования в области психологии потребления стали работы А. Тверски, Д. Канемана, Р. Багоцци, Ц. Герхан-Канли, Й. Пристер, В.А.Хащенко [4], О.И. Патоши [5], Т.В. Дробышевой [6], а также результаты наших предыдущих исследований [7]. В области психологии управления покупателем научной базой стали работы Р. Чалдини, Б. Вансинка, Т. Ребрика, А.А. Деревицкого. В области Я-концепции потребителя работы В.В. Столина [8], Е.Л. Доценко и Т.Л. Сморкаловой [9], М. Сирджи [10].

Интегративный подход позволил нам опираться на труды экономистов и маркетологов, субъектно-деятельностный подход - рассматривать деятельностные основы поведения потребителей.

Я-концепция, согласно определению многих отечественных учёных, - система представ- лений индивида о самом себе, осознаваемая, рефлексивная часть личности. Эти представления о себе самом в большей или меньшей степени осознаны и обладают относительной устойчивостью. Некоторые исследователи считают, что Я-концепция - это не просто Я-образ, а система Я-образов (Я-реальное, Я-идеальное, Я в будущем, Я в прошлом, Я-социальное и т.д.) плюс самооценка. Другие синонимами данного термина считают «самосознание». Я-концепция имеет следующие составляющие: оценочную, содержательную, поведенческую.

Систематизировав работы отечественных и зарубежных учёных, Е.Л. Доценко и Т.Л. Сморкалова [8] сформулировали следующее определение Я-концепции: Я-концепция - это система множественных установок по отношению к себе на основе представлений о себе, отношения к себе, в соответствии с которыми человек объясняет и организует свое поведение. Я-концепция складывается на основе интеракций с окружающей средой, развиваясь в процессе самоактуализации и позитивного отношения со стороны других.

Но Я-концепция потребителя как единица общей Я-концепции описана лишь на западе и не слишком совпадает с традициями отечественной психологии (Р. Белк, Э. Грабб, И. Долич, Н. Малхотра, И. Росс, М.Дж. Сирджи, Г. Хапп, А. Хит, К. Шенк, Р. Холман). В российскую психологию это понятие внедрено Т.Л. Сморкаловой и Е.Л. Доценко [9].

В зарубежной психологии Я-концепция в широком смысле и Я-концепция потребителя трактуются синонимично. Но и наши исследования, и исследования Т.Л. Сморкаловой [9] показали, что в российской ментальности это вовсе не так.

Для зарубежных психологов-практиков и ученых-психологов общим местом является стремление изучить Я-концепцию человека для прогнозирования результатов потребительского поведения.

Под Я-концепцией применительно к потреблению понимается [10] общая сумма идей, мыслей и чувств, через которые человек может описать себя в социальной среде. Большинство ученых дают упрощенную формулу: Я-концепция = самооценка + Я-образ, в некоторых вариантах он же - самосознание (consumer Self-conception $=$ consumer selfesteem + self-image).

Обычно выделяется 4 вида Я-образов в рамках Я-концепции потребителя: Я-реальное (или в некоторых вариантах Я-фактическое), Я-идеальное, Я-реально-социальное (как люди 


\section{Горизонты психологии}

считают, какими их воспринимают значимые для них другие люди) и Я-идеально-социальное (как люди хотели бы, чтобы их воспринимали значимые для них другие люди).

Выделяют также и Я-зеркальное, но одни авторы используют этот термин как синоним Я-реально-социального, другие же выделяют его как пятый тип, который означает «Я, начинающий себя вести так, как обо мне говорят другие». Я-зеркальное хорошо иллюстрируется русской поговоркой «Сто раз назови человека бараном - на сто первый он заблеет».

В редких источниках выделяется Я-ожидаемое каким потребитель ожидает увидеть себя в какойто момент времени в будущем (аналог привычного нам Я-в-будущем). Интересно, что Я-в-прошлом, Я-в-настоящем применительно к потреблению не рассматриваются.

Некоторые авторы применяют эти типы не только к Я-образу, но и к самооценке, выделяя 4 типа самооценок потребителя: реальную, идеальную, реально-социальную, идеально-социальную. Несоответствие между реальной самооценкой и идеальной самооценкой - мощный стимул купить определенные продукты (т.е. женщина, недовольная своим весом, купит продукты, помогающие сбросить вес и т.д.). Самооценка, как правило, положительно связана с материальным положением человека! Но субъективное ощущение счастья, субъективное благополучие с материальным положением не связаны.

Общим местом зарубежных исследований [11; 12] является мнение, что самосознание тесно связано с потребляемыми товарами и услугами, причем связь эта двусторонняя: Я-образ формируется, в том числе и товарами/услугами, а покупка товаров/услуг определяется самосознанием. Товары становятся способом формирования и отражения своего Я-образа. Д. Аакер убеждён, что люди покупают продукты и бренды, потому что это позволяет им сказать миру что-то положительное о себе. Причем отмечается, что возникает не когнитивная, а эмоциональная связь Я-концепции с тем или иным продуктом. Эмоциональная связь с продуктом является основой «пожизненных» отношений брэндов с клиентами. В маркетинге используется оксюморонный термин «эмоциональные выгоды». Несмотря на то, что выгода обычно рациональна, когда человек покупает товар, он зачастую именно на эмоциях принимает решение, выгодна ли эта покупка.
Более того, отмечается [13], что человек соизмеряет свою самооценку и Я-образ с оценкой и образами постоянных покупателей данного продукта. Долгосрочные покупки данного брэнда возможны только в том случае, если человеку комфортно быть похожим на основных покупателей данного товара. Этим широко пользуются в рекламе, приглашая сниматься звезд эстрады, спорта и политики. Подсознательно покупатель приближается к ним, покупая рекламируемый ими товар.

Сейчас психологи считают [13; 14], что подобные взаимосвязи с имиджем продукта и имиджами основных покупателей должны быть не у Я-концепции потребителя в целом, а именно у Я-идеального. Я-идеальное определяет покупки товаров публичного потребления (другие названия: видимое, заметное, открытое потребление потребление товаров, которые видны всем окружающим: одежда, обувь, косметика и т.п.). Я-реальное, в свою очередь, обуславливает покупки товаров личного потребления (другие названия: незаметное, частное - потребление товаров, которые видны только самым близким: еда, белье). При покупке первых - есть к чему стремиться, а при покупке вторых - есть на чем сэкономить. Также считается [14], что товары публичного потребления покупают для повышения самооценки, уверенности в себе и социального статуса. Покупка же товаров личного потребления не коррелирует ни с какими социальными и личными характеристиками, т.е. эти покупки строго индивидуальны и соотносятся с неприкосновенностью частной жизни. Соответственно, в рекламе товаров публичного потребления должна рекламироваться идеальная жизнь, а главный герой соответствовать Я-идеальному целевой аудитории. Это должен быть не идеальный герой, а именно воплощение Я-идеального тех людей, кто в дальнейшем будет покупать этот товар. T.е., к примеру, масло должна рекламировать не юная фотомодель, а привлекательная домохозяйка средних лет.

Управление самооценкой клиента - это ключ к управлению продажами! Вот совет маркетологапрактика: «Управление самооценкой клиента поможет вам позиционировать компанию/товар. Так клиенты эмоционально присоединятся к вашему товару, и у них разовьется лояльность». Это очень простой способ - поднять самооценку не развитием личности, а купив сумочку известнейшего брэнда. В этом смысл многих манипуляций потребителем. Базовой идеей многих зарубежных исследований 
является мысль: люди склонны поддерживать и укреплять свою самооценку потреблением известных брендов и определенных продуктов.

Особое место в западных исследованиях отводится потреблению товаров как нужных символов: человек покупает не сам товар, а его атрибуты, т.е. элементы, характеристики, как символы того, что нужно поведать миру о себе (суперсовременный автомобиль как символ успеха и богатства и т.п.). «Потребительское поведение индивида направлено на обеспечение и повышение его Я-концепции через потребление товаров в качестве символов» [10, р. 12].

Американские исследователи [12; 14; 15; 16] констатируют стереотипность Я-концепции. Стереотипность рассматривается как механизм, с помощью которого потребитель может не вникать в технические, конструкторские и другие детали товаров, а выбирать по некоторым стереотипным, зарекомендовавшим себя «маркерам»: названию, наличию какого-либо ингредиента и т.п. Кстати, реклама использует стереотипность Я-концепции потребителя: она никогда не описывает товар, она показывает только эти «маркеры» (они же «символы»).

Кроме того, роль потребления в Я-концепции - это формирование и демонстрация своей идентичности и позиционирование себя по отношению к другим. Люди покупают продукты, чтобы укрепить свой Я-образ и имидж (к примеру, покупая брэндовое мыло с логотипом в виде голубя, люди подсознательно покупают женственность, поскольку доказано, что это изображение подсознательно ассоциируется именно с женственностью. Покупая брэндовую пену для бритья, мужчины покупают мужественность)

Согласно теории Я-конгруэнтности [12; 16] существует взаимосвязь Я-образов и предпочитаемых брэндов. Предполагается, что потребители сравнивают свою самооценку и свой Я-образ с оценкой и образом (имиджем) продукта. Люди предпочитают продукт, образ и оценка которого совпадет с их Я-образом и самооценкой. Т.е. маркетологам, чтобы продать товар, необходимо, чтобы Я-концепция полностью соответствовала имиджу продукта (self-concept product-image). Эту же мысль выдвигал Г. Лэндон (Landon, 1974) более четверти века назад, говоря, что покупатель выбирает те товары и тех поставщиков, имидж которых сходен с его Я-образом.

Важная закономерность Я-концепции потребителя заключается в том, что Я-концепция сопротивляется изменению: человек склонен покупать новые товары, сходные с его предыдущими покупками. Человек боится чересчур сложных инноваций. Поддержать Я-концепцию, а не изменить её вот задача маркетолога.

Человек всегда соизмеряет свои действия и свой Я-образ с действиями и образами других людей: в магазинах человек всегда смотрит, что покупают другие. Люди с низкой самооценкой склонны копировать действия других и покупки других, с высокой - нет. Заметим, что наши фокус-группы показали, что подобная склонность повторять связана не с самооценкой, а со знанием именно этой товарной категории: человек, хорошо разбирающийся в данном товаре, независимо ни от самооценки, пола, возраста и т.п., не повторяет действия других покупателей. А человек, не разбирающийся в особенностях данной товарной категории, всегда ориентируется на других как на образец, и это не связано с его самооценкой.

Потребители используют брэнды, (1) чтобы пробудить чувство сопричастности, например, к кумиру, который рекламирует этот товар, к успешным людям и т.п., чтобы избавиться от чувства социальной изоляции, (2) чтобы выделиться в группе, отличиться.

С. Доммер и соавторы [14] выделили два типа брэндов по использованию Я-концепции в их маркетинговой политике: «горизонтальные» и «вертикальные» бренды.

«Горизонтальные» брэнды - марки, позволяющие человеку быть включенным в важную для него социальную группу, не отличаться от среднего члена группы (проведем параллель с российскими рекламными кампаниями: «Пепси - вливайся!»).

«Вертикальные» брэнды - марки, помогающие продемонстрировать степень превосходства над другими людьми. Чаще всего это люксовые марки.

Хотя в российских реалиях мы бы добавили еще и «индивидуальные» брэнды, в качестве третьего вида или в качестве подвида вертикальных брэндов, идеей брэндинга которых является концепция «Будь собой».

Люди, чувствующие себя социально изолированными, как правило, показывают глубокую привязанность к «горизонтальным» брендам, поскольку они позволяют людям защитить себя от чувства изоляции. Эти люди пытаются вписаться в группу, а не выделиться из нее. Люди с низким чувством собственного достоинства, с низкой самооценкой, выбирают «вертикальные» брэнды, которые позволяют им повысить свой статус. 
В рекламе используются следующие стратегии влияния на Я-концепцию потребителя:

- Предоставление возможности решить проблемы, которые нельзя решить без рекламируемого товара.

- Убеждение, что с этим товаром люди будут чувствовать себя лучше.

- Предоставление определенного статуса, достигаемого именно с этим товаром.

- Предоставление «чувства бессмертия», потому что продукты проверены многими поколениями.

- Предоставление «магической силы». Существует две основных формы влияния на Я-концепцию потребителя:

1. Информационное влияние - влияние информации полученной из СМИ, от друзей и т.д.;

2. Нормативное влияние - влияние социальных норм (положено мыть руки перед едой, положено менять вид зубной пасты раз в несколько месяцев). Но социальные нормы также устанавливают люди. К примеру, уже мало кто помнит, что «правильный» цвет одежды Санта-Клауса - зеленый. Однажды Coca-Cola «переодела» его в свои фирменные цвета, таким он и приходит в каждый дом уже более полувека.

Нормативное влияние имеет 2 аспекта:

1. Экспрессивное влияние - сходство с другими по поведению и внешним атрибутам придает вес человеку в социальной группе.

2. Утилитарное влияние - необходимо делать то, что делают другие, чтобы получить награду и избежать порицания.

\section{Обработка результатов эмпирического исследования}

Выборку исследования составили представители молодежи г. Калуги в возрасте от 18 до 35 лет различного социального положения и дохода (N = 154). Были применены следующие методы: теоретический анализ, фокусированное групповое интервью, тестирование (модифицированная методика М. Куна), анкетирование (анкета, построенная по принципу «незаконченные предложения»), игровое моделирование (игра «Миллион», в которой необходимо помечтать, куда потратить миллион рублей), проективная диагностика (рисуночная методика «Я в магазине в метафоре «дерево»).
Получили, что Я-концепция потребителя - это часть общей Я-концепции, самовосприятие себя как потребителя (покупателя и пользователя товарами/услугами), система эмоционально окрашенных представлений о себе как о потребителе во взаимосвязи с выбираемыми товарами, с флуктуирующим уровнем осознанности. Так как это частное звено общей Я-концепции, большинство черт характера проявляется и в Я-образе потребителя, активируясь в торговом зале (например, я стеснительный потребитель, я вежливый потребитель, я рассудительный потребитель). Т.е., 77 \% характеристик «потребительского Я» являются чертами характера, но именно эти черты характера важны для успешной покупки. 22 \% характеристик специфичны именно для покупок, для торговых залов (например, Я активный потребитель, Я выгодный потребитель, Я нервничающий потребитель, Я разборчивый потребитель, Я избирательный потребитель). И лишь $1 \%$ высказываний косвенно относится к потреблению (например, Я лысый потребитель, я красивый потребитель, я толстый потребитель). Таким образом, в 99 \% случаев респонденты рефлексируют свой Я-образ потребителя.

Я-концепцию потребителя нельзя отождествлять с Я-образом: она включает в себя Я-образ потребителя, а также потребительскую самооценку, уровень потребительских притязаний, потребительские представления о присвоенных товарах (нужных, купленных, т.е. психологически своих).

По итогам исследования выявлены свойства Я-концепции потребителя, которые мы условно разделили на маркетинговые и психологические. Маркетинговые свойства Я-концепции потребителя - те, которые позволяют нашему «Я» быть податливым к внешней стимуляции сделать покупку. Причём в большинстве своем эти покупки не жизненно необходимы, а из серии «совсем не лишних», «пусть будет», «не нужно, но очень мило». Т.е. это те свойства, вследствие которых человек теряет свою субъектность и приобретает объектность, становится объектом рекламного и другого воздействия. Поэтому иначе мы назвали эти свойства объектными свойствами Я-концепции. Психологические свойства Я-концепции потребителя те, которые заставляют его быть субъектом, т.е. реагировать на скидки, распродажи, акции сквозь когнитивную прослойку и не совершать ненужных, необдуманных покупок. Поэтому иначе мы назвали их субъектными свойствами Я-концепции потребителя. 


\section{Психология и психотехника 5(80) • 2015}

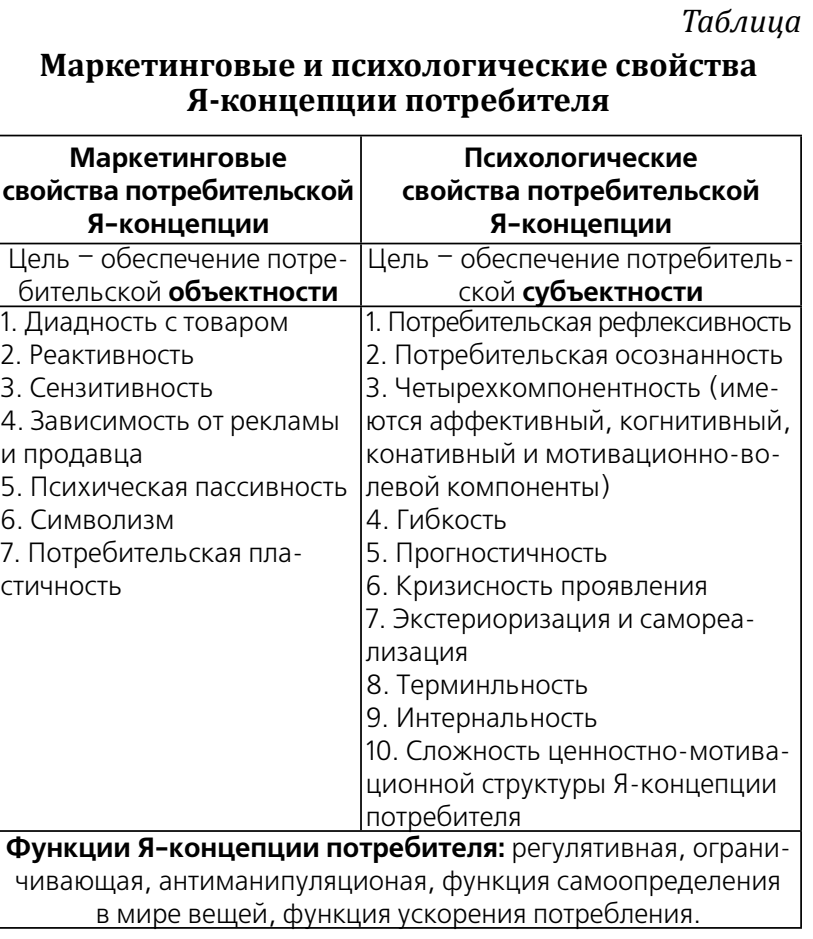

Представим маркетинговые свойства Я-концепции потребителя. Их значение - обеспечение потребительской объектности.

\section{Маркетинговые свойства Я-концепции потребителя}

1. Диадность с товаром. Принципиальным новообразованием Я-концепции потребителя в отличие от общей Я-концепции является ее диадность с товаром, т.е. сочлененность «Я» с товаром. Ее нельзя рассматривать в разрыве от потребляемых товаров: от отношения к товарам, от предпочтения товаров, от перцепции товаров. Некоторые товары становятся неотъемлемой частью Я-концепции. К примеру, для многих выйти из дома без сотового телефона просто невозможно. Этот товар уже стал «приклеен» к личности. И у каждого человека имеется около десятка таких товаров, которые стали частью его «Я»: для некоторых это автомобиль, для других - духи определенной марки, для третьих - определенная еда и т.п. И именно поэтому Я-концепцию потребителя необходимо рассматривать только в диаде «человек - товарная категория». К примеру, в плоскости «Я и автомобили» у мужчины одни особенности Я-образа, вербализованные им, к примеру, как «я хороший водитель, я специалист; я разбираюсь в устройстве автомоби- лей и т.п.», а в плоскости «Я и одежда» будет совершенно иной Я-образ, вербализованный в итоге как «Я почти профан, Я непритязателен; мне не слишком интересен мой гардероб». И ведь это не просто особенности потребительского отношения к разным товарным группам, а именно включенность их в свое Я. Вообще, «отоваренное мышление», на наш взгляд, серьезная проблема общества. И чем активнее работает прикладная психология продаж, тем ценнее становится научный противовес этой психологии.

2. Реактивность - человек реагирует на имеющееся предложение, но не слишком склонен к планированию, прогностичности, т.е. реализует себя в сложившейся ситуации, а не пытается поменять ситуацию! Человек здесь - объект маркетингового воздействия, а не субъект своей жизни.

3. Сензитивность или она же интуитивность многие потребители покупают исходя отнюдь не из логики, и даже не из эмоций, а именно интуиции. Как описывали респонденты в самоотчетах, «сердцем чувствовали».

4. Зависимость от общения с продавцом-консультантом - талантливый продавец может «раскрутить» человека на незапланированную покупку. К примеру, фразы «А пирожок?», «Может, картошечку?» в известном ресторане быстрого питания существенно повышают продажи. Что уж говорить о ситуациях в бутиках, когда продавец может предложить целый ворох разнообразных товаров.

5. Психическая пассивность - человек крайне ленится скрупулезно выбирать и останавливается на том, что ближе всего к глазам и рукам, или уходит без покупки. Даже шопоголики не всегда заглядывают на верхние или нижние полки, дальние углы торгового зала. Именно поэтому на «золотых полках» (на уровне глаз), в «горячих зонах» (на кассе и у входа в зоне ближайшей видимости) товары продаются гораздо интенсивнее, чем эти же товары, но лежащие на других полках (эти эксперименты проводятся мерчендайзерами и маркетологами во многих крупных торговых сетях).

6. Символизм - большинство товаров выбираются как символы либо себя самого, либо нужного имиджа, либо нужного образа жизни. Человек не покупает товары как таковые - он покупает их как символы чего-то важного для него. Исключение составляют лишь товары повседневного спроса, которые человек покупает машинально, по привычке, по сути, почти не выбирая (еда, бытовая химия, билеты на общественный транспорт). 


\section{Горизонты психологии}

7. Также в Я-концепции потребителя ярко проявляются такие характеристики психики, как пластичность-ригидность. Некоторые так зацикливаются на поиске нужного товара, что тратят на его поиски едва ли не месяцы (замечено, что это в абсолютном большинстве это женщины) - это потребительская ригидность. Другие же покупают первую попавшуюся из необходимых вещь (это пластичность). И первый, и второй полюс крайне нежелательны в потреблении.

Перечислим психологические свойства Я-концепции потребителя. Их значение - обеспечение потребительской субъектности.

\section{Психологические свойства Я-концепции потребителя}

1. Потребительская рефлексивность склонность к анализу и самоанализу мыслей при выборе товара, потребительского поведения. Интересны наши предварительные наблюдения: чем больше денег в кошельке или на карте, тем меньше человек рефлексирует об объективной необходимости товара. И наоборот, когда денег мало, человек крайне невосприимчив к рекламе, предложениям продавцов, акциям и т.п. и старается логически оценивать необходимость товара. В Я-образе потребителя сохраняются две базовых составляющие, выделенные основоположником изучения Я-образа У. Джемсом [4]: Я познающее (I) и Я познаваемое (me). Впоследствии «I» и «те» стали переводить «Я как субъект познания» и «Я как объект познания». Но в экономическом сознании «познаваемое Я» выражено чересчур слабо, оно проявляется явно лишь на стыковых областях, на стыке потребления и эстетического драйва: например, девушка, подбирая одежду, постепенно понимает, какие фасоны ей идут, а какие нет. И здесь активно работают и познающее, и познаваемое Я. Вопрос лишь в том, что в такие моменты возникает ее самопознание, саморефлексия в эстетическом, плане, и только во вторую - в потребительском.

2. Потребительская осознанность. Знание о товаре. Если индивид хорошо разбирается в данной товарной категории, то чаще всего он будет выбирать уникальные товары, индивидуальные, подчеркивающие и развивающие его Я-образ. Если индивид слабо разбирается в данной товарной категории, то он будет выбирать товары, активно рекламируемые, пользующиеся наибольшим спросом в его референтных группах, и Я-концепция в такие моменты не включается. Как говорится, все маркетологи мира бессильны против заранее составленного списка покупок.

3. Четырехкомпонентность. Я-образ потребителя включает в себя 4 взаимосвязанных структурных компонента (указаны по мере осознаваемости респондентами): аффективный, когнитивный, конативный, мотивационно-волевой. Причем каждый компонент направлен в две стороны: на себя (к примеру, Я экономный покупатель, я ненавязчивый клиент), и по отношению к личностно значимому товару (к примеру, я чувствую радость, когда ем мороженое; я негодую, когда в магазине нет моего размера понравившейся одежды). И если ко всему многообразию товаров наблюдается обычное психологическое отношение, то отношение к личностно значимым товарам - это уже субстрат, «вросший» в Я-образ.

4. Гибкость. Я-образ потребителя не является системой установок о себе, как большинство других Я-образов (к примеру, я хорошая мать, Я опытный психолог и т.п.). Установки - психическая субстанция, строго зафиксированная в сознании. Но большинство наших респондентов испытывали трудности не только при формулировке установок о себе, но и в рефлексии себя в торговом зале. Я-образ потребителя является системой именно представлений о себе и отношений к себе - более «мягких» психологических образований. К тому же, по А.Г. Асмолову, установка предполагает выраженную готовность к действию, но вышеуказанные диаграммы не демонстрируют таковой в потреблении. Готовность покупать строго ограничена финансами, и если имеется, то не готовность, и даже не потребность, а именно мечта, желание, фантазия купить что-либо.

5. Прогностичность или целеполагание. Люди, склонные к прогнозированию, просчитывают свое взаимодействие с покупаемым товаром не на один шаг, а на несколько. И в большинстве случаев при таком прогнозе отказываются от многих вещей.

6. Кризисное проявление. Я-концепция активно проявляется в любой критической ситуации: стресс, кризис, проблема и т.п. В них просыпается понимание «это мое», «это Я». Когда все в порядке, человеку незачем проявлять свое «Я».

7. Я-концепция потребителя характеризуется не столько интериоризацией (усвоением и присвоением правил внешнего мира), сколько экстериоризацией по Л.С. Выготскому (объективацией 
внутреннего мира) и самореализацией. Несмотря на то, что современному потребителю приходится познавать множество новинок техники, подобная интериоризация есть мыслительный акт, акт познания и интеллектуально-эмоционального присвоения инноваций, но слабо связана с самооценкой и Я-образом человека.

8. Я-концепция потребителя относится к терминальным, но не инструментальным новообразованиям - она важна сама по себе, а не как инструмент достижения каких-либо целей - выгодных покупок, качественного применения товаров и т.п.

9. Кроме того, на осознанность потребления влияют интернальность и сложность ценностномотивационной структуры личности.

Кроме вышеперечисленного, на субъектность Я-концепции потребителя влияют следующие функции Я-концепции потребителя. Регулятивная (регулирующая) функция Я-образа в целом, детально описанная К. Левиным, Ф. Хоппе, С.Г. Якобсоном, Г.И. Моревой, Д.Б. Элькониным, Т.В. Драгуновой является ведущей и в потреблении. Помимо этого, важная функция Я-образа потребителя ограничивающая: если от необдуманных и не совсем нужных покупок личностно незрелого человека ограничивает недостаток денежных средств, то личностно зрелого - удовлетворенность многих потребностей и его «самость». Третья функция - самоопределение в мире вещей. Четвертая - антиманипуляционая. Чем сильнее развито у человека его потребительское Я, тем меньше он становится жертвой рекламы, промоушна, акций, конкурсов и участвует в последних только в том случае, если они ему действительно нужны. Критерием объективной нужности здесь выступает то, что в последующем человек не будет жалеть о сделанных покупках и будет ими пользоваться. Следующая функция - ускорение потребления: человек, детально знающий свое Я, свои вкусы, осознающий свои гастрономические, эстетические, эргономические пристрастия, не тратит время на осмотр тех вещей, которые не соотносятся с его Я-концепцией.

Исходя из вышеперечисленного, налицо факт внутреннего конфликта, внутренней несбалансированности между внешними стимулами оставить свои деньги в данном магазине за данный товар и внутренним желанием каждого потребителя делать только нужные покупки.

Ведомые желанием проверить промежуточную гипотезу о внутреннем дисбалансе и незрелости по- требительской и Я-концепции у молодежи, мы провели анкетирование, в котором нам было важно изучать соотношение «Я» с составляющими потребления: деньгами, процессом шопинга и покупками. Было предложено заполнить середину фраз «Я деньги», «Я _ экономить», «Я _ транжирить деньги», «Я _ многочасовой шопинг», «Я _ покупки». Разрешалось менять окончания последних слов.

Интересно, что отношение калужской молодежи к деньгам в основном эмоциональное, нерациональное: люблю / обожаю (29 \%), не люблю / не очень люблю (12 \%), спокойно отношусь (4 \%). Для некоторых самое главное - установки об экономии: экономлю / берегу (9\%), транжирю / легко трачу (11\%). Для других деньги относятся к обыденному сознанию: ношу с собой (4\%), имею (7 \%). Есть и проявление внутренних конфликтов: я и деньги несовместимы (5\%), я трачу, но не зарабатываю (3 \%). Тех, для кого деньги не эмоционально важны, а именно ценны - немного: я ценю деньги / я знаю цену деньгам (6 \%). Достаточно тех, кто хочет денег (6\%), но лишь один человек в выборке отметил, что не просто хочет денег, а хочет именно «зарабатывать хорошие деньги». Для 4 \% важно копить деньги. Так, отношение к деньгам совершенно синкретично, эмоционально и не связано с их зарабатыванием и грамотной тратой.

Рассмотрено место экономии в Я-концепции потребителя: я не могу / не умею экономить (26 \%), стараюсь (16 \%), могу / умею (15\%), не люблю / ненавижу (15 \%), люблю (10 \%), умею (8 \%), часто экономлю (6 \%), учусь (3 \%), считаю нужным (1 \%).

Затем рассмотрено место трат в Я-концепции потребителя. Оказалось, что оно более широко: стараюсь / стремлюсь / пытаюсь не транжирить деньги (29\%), я могу / умею транжирить деньги / у меня хорошо получается (21\%), не имею привычки / не привык/ не приучен (17\%), иногда могу (14\%), я люблю / обожаю транжирить деньги (12\%), редко это делаю (4 \%), ненавижу (3 \%).

Отношение к процессу многочасового шопинга абсолютно эмоционально: я не люблю (36 \%), люблю / обожаю (29\%), ненавижу / терпеть не могу (9 \%), меня утомляет / я устаю (11\%), я и многочасовой шопинг несовместимы / у меня такого не бывает (15\%).

Отношение к покупкам высокоэмоционально: люблю делать (60 \%), люблю удачные (12 \%), не умею делать правильные / хорошие (12\%), я внимателен / требователен / избирателен / придирчив к покупкам (16 \%). 


\section{Горизонты психологии}

Таким образом, все околопокупочные процессы в Я-концепции потребителя совершенно эмоциональны и слабо связаны со здравым смыслом, выгодой от покупок, их логическим анализом.

Затем мы изучили актуальные потребительские желания (потребности) молодежи, которые были бы реализованы, если бы у респондентов отсутствовали финансовые ограничения. Для этого была предложена игровая ситуация «Миллион», при которой каждому предлагалось представить ситуацию, что к ним в руки волшебным образом попал миллион рублей, который не нужно отдавать. На что бы его потратили? Нас не интересовало количество денег, затраченных на ту или иную покупку. Тем более, оказалось, что люди в большинстве своем финансово не осведомлены. Нас интересовала лишь значимость товаров в Я-концепции потребителя. Представим проранжированные результаты: ранг выявлен по количеству людей, «потративших» деньги именно на эту покупку. Итак, наиболее значимыми в Я-концепции из нереализованных товарных потребностей стали: машина, отдых (поездка на море, путешествие), квартира (комната). На четвертом месте и далее: текущие расходы, реализация давней мечты родителей, чаще мамы (квартира, путевка на отдых, дом в деревне, ремонт, бытовая техника, папе ружье, маме серьги и т.д.), отдать часть денег родителям, одежда, развлечения, дача/дом, ремонт, еда, важные давние мечты (футбольный мяч, велосипед, собака, сладости, шуба, зеркало, украшения, шкаф для одежды, телефон, компьютер, мотоцикл, катер, квадроцикл, фотоаппарат), хобби, посещение салона красоты, положить в банк под проценты, пластическая операция (чаще - груди), открытие своего бизнеса, подарки родственникам. Почти треть думает о благотворительности, причем очень синкретично - мало кто адресно указывал, кому конкретно он поможет.

Так, если в советское время у молодежи были установки на «отдать» (сделать выработку, выполнить норму производства и т.п.), в постперестроечный период - «взять» (заработать, сэкономить), то сейчас ситуация выравнивается - респонденты пытаются и сами получать выгоду, и помогать ближнему. Советская установка «примат общественного над личным», от которой, как от огня, бежали в постперестроечный период, когда стали доминировать американизированные индивидуалистические ценности, теперь опять актуальна. Но сегодня соотношение личных и общественных благ в умах людей постепенно выравнивается, что не может не радовать.

Оказалось, что если такая часть экономического сознания как потребительское сознание, у молодежи развито на достаточном уровне, то денежное сознание - не слишком: респонденты с трудом ориентируются в ценах и слабо рефлексируют финансовые процессы.

Для изучения проективного пласта Я-концепции потребителей респондентам была предложена классическая проективная методика «Дерево», в модификации: нарисуйте себя в любимом магазине, в виде дерева. У абсолютного большинства дерево нарисовано на весь лист - это свидетельствует о самоуверенности, открытости, нестеснительности в магазинах. Среднее дерево представлено у трети и это, главным образом, юные респонденты, еще не имеющие большого опыта самостоятельных покупок. Конечно, более чем у половины респондентов дерево нарисовано в середине листа, у многих - вверху, что свидетельствует об идеализировании своего состояния.

У многих рисунков дерева огромная круглая или овальная крона - респонденты находятся в состоянии комфорта и максимальной самореализации, но у трети респондентов при этом много острых деталей: веток, острых листьев, шипов, что говорит о когнитивном диссонансе во время посещения магазинов. Корни или фундаментальная опора прорисованы у абсолютного большинства испытуемых, что трактуется как ощущение надежности и психологической устойчивости, а также любопытство, тяга к скрытому и запретному. Склонность к украшению своих деревьев говорит о демонстративности, кураже: яблоки, цветы, фантазийный орнамент, торты вместо листьев, новогодние игрушки, глаза, руны.

Острые чётко прорисованные ветки говорят об агрессии. Они прорисованы у двух третей испытуемых. Ветки в разные стороны характерны для трети рисунков, что говорит об их поиске самоутверждения, контактов, самораспылении, суетливости, чувствительности к окружающему миру, отсутствии противостояния ему. Ветви вверх - у десятой части рисунков, что говорит об их активности, порывах, энтузиазме. Столько же прорисовано веток, направленных вниз, что свидетельствует об отказе от усилий. По комментариям рисующих (которые было трудно получить и истолковать), это агрессия в сторону недостатка денег на покупку. 


\section{Психология и психотехника 5(80) • 2015}

\section{Выводы:}

1. Я-концепция потребителя - часть общей Я-концепции, система эмоционально окрашенных представлений о себе как о потребителе во взаимосвязи с выбираемыми товарами, с флуктуирующим уровнем осознанности.

2. Я-концепция большинства потребителей характеризуется внутренним дисбалансом между тремя векторами: (1) представлениями большинства потребителей о необходимых и желательных товарах, (2) процессом их выбора, (3) Я-образом. В этом разрыве кроется, на наш взгляд, высокий уровень потребительской незрелости, который приводит к ситуативной подверженности рекламному, промо- и мерчендайзинговому воздействию.

3. К маркетинговым свойствам Я-концепции потребителя, т.е. тем, которые обеспечивают активное реагирование на внешнюю стимуляцию продаж, и тем самым, потребительскую объектность, относятся: диадность с товаром, реактивность, сензитивность, зависимость от рекламы и продавца, психическая пассивность, символизм, пластичность.

4. К психологическим свойствам Я-концепции потребителя, тем, которые обеспечивают субъ- ектный контроль покупок, относятся: потребительская рефлексивность, осознанность, прогностичность, целеполагание, кризисное проявление, экстериоризация личности, самореализация, терминальность, интернальность, сложность ценностно-мотивационной структуры личности.

5. Я-концепция потребителя характеризуется в большинстве случаев аффективным самоописанием. Когнитивный, конативный, мотивационноволевой компоненты представлены минимально. В связи с этим, эмоциональное воздействие продавца, оформления магазина, рекламы и т.п. дает гораздо больший эффект, нежели логическое объяснение преимуществ товара.

6. Я-концепция потребителя обладает следующими функциями: регулятивная, ограничивающая, антиманипуляционая, функция самоопределения в мире вещей, функция ускорения потребления.

7. Основные траты молодежи - на реализацию мечты и поднятие своего престижа, а не на объективно необходимые товары, не долгосрочные вложения, что говорит о чрезмерной подверженности внешним установкам и потребительской конформности.

\section{Список литературы:}

1. Ж Журавлев А.Л., Купрейченко А.Б. Экономическое самоопределение. Теория и эмпирические исследования. М.: Издво «Институт психологии РАН», 2007. 480 с.

2. Неверов А.Н. Концепция ноосферной стадии эволюции социально-экономических систем: Дисс. ... доктора экономических наук. Саратов, 2012. 385 с.

3. Спасенников В.В. Экономическая психология: современные тенденции и перспективы развития // Вопросы психологии. 2011. № 1. С. 150-152.

4. Хащенко Т.Г. Психологическое сопровождение экономического самоопределения личности в процессе её профессионализации в отраслевом вузе // Психология и психотехника. 2014. № 8. C. 855-862. (DOI: 10.7256/20708955.2014.8.12327. URL:http://www.nbpublish.com/go_to_article.php?id=30476).

5. Кочанова Е.С., Патоша О.И. Общество потребления: феномен материализма // Экономическая Психология: прошлое, настоящее, будущее. Вып. 2. Материалы II Международной научно-практической конференции, 15-17 мая 2014 г. / Под ред. А.Н. Неверова. Саратов, 2014. С. 292-302.

6. Дробышева Т.В. Экономическая социализация личности: ценностный подход. М.: Изд-во «Институт психологии РАН», 2013. 312 c.

7. Посыпанова О.С., Воробьева О.С. Субъект-предметные и объект-предметные отношения в потреблении // Психология и психотехника. 2014. № 10. C. 1021-1032. (DOI: 10.7256/2070-8955.2014.10.12779).

8. Столин В.В. Самосознание личности. М.: Изд-во МГУ, 1983. 286 с.

9. Сморкалова Т.Л., Доценко Е.Л. Место Я-концепции в потребительских предпочтениях: рабочая модель // Вестник Тюменского государственного университета. 2011. № 9. С. 182-189.

10. Sirgy M.J. Self-concept in consumer behavior - Diss. PhD / Institute: University of Massachusetts Amherst, 1979.120 p.

11. Starcevic S. Self-concept as a significant determinant of brand choice and consumer buying behavior // Marketing. 2001. Vol. 42, No. 2, pp.106-117.

12. Asif Khan M., Bozzo C. Connection between self-concept and brand preference and the role of product usage // International IJAS Conference for Academic Disciplines, 13-16 March 2012, Las Vegas, USA (http://www.cergam.org/fileadmin/files/ cerog/wp/912.pdf).

13. Azar Ofer H. Tipping Motivations and Behavior in the US and Israel // Journal ofApplied Social Psychology. 2014. 40 (2), pp. 421-457. (URL: http://www.nbpublish.com/go_to_article.php?id=31238). 
14. Dommer S., Swaminathan V., Ahluwalia R. Using Differentiated Brands to Deflect Exclusion and Protect Inclusion: The Moderating Role of Self-Esteem on Attachment to Differen-tiated Brands // Journal of Consumer Research. 2013.40 (4), pp. 657-675.

15. Villarino R.R., Otero-Lopez J.M. April Lane Benson (ed.): I shop therefore I am: compulsive buying and the search for self; Susanne Friese: Self-concept and identity in a consumer society: aspects of symbolic product meaning // Journal of Consumer Policy. 2001. T. 24. № 3-4, pp. 441-447.

16. Reed A.Ii. Social Identity as a useful perspective for self-concept-based consumer re-search // Psychology \& Marketing. 2002. T. 19. № 3, p. 235.

\section{References (transliteration):}

1. Zhuravlev A.L., Kupreichenko A.B. Ekonomicheskoe samoopredelenie. Teoriya i empiricheskie issledovaniya. M.: Izd-vo «Institut psikhologii RAN», 2007. $480 \mathrm{~s}$.

2. Neverov A.N. Kontseptsiya noosfernoi stadii evolyutsii sotsial'no-ekonomicheskikh sistem: Diss. ... doktora ekonomicheskikh nauk. Saratov, 2012. $385 \mathrm{~s}$.

3. Spasennikov V.V. Ekonomicheskaya psikhologiya: sovremennye tendentsii i per-spektivy razvitiya // Voprosy psikhologii. 2011. № 1. S. 150-152.

4. Khashchenko T.G. Psikhologicheskoe soprovozhdenie ekonomicheskogo samoopredele-niya lichnosti v protsesse ee professionalizatsii v otraslevom vuze // Psikhologiya i psikho-tekhnika. 2014. № 8. S. 855-862. (DOI: 10.7256/20708955.2014.8.12327. URL:http://www.nbpublish.com/go_to_article.php?id=30476).

5. Kochanova E.S., Patosha O.I. Obshchestvo potrebleniya: fenomen materializma // Ekonomicheskaya Psikhologiya: proshloe, nastoyashchee, budushchee. Vyp. 2. Materialy II Mezhdunarodnoi nauchno-prakticheskoi konferentsii 15-17 maya 2014 g. / Pod red. A.N. Neverova. Saratov, 2014. S. 292-302.

6. Drobysheva T.V. Ekonomicheskaya sotsializatsiya lichnosti: tsennostnyi podkhod. M.: Izd-vo «Institut psikhologii RAN», 2013. 312 s.

7. Posypanova O.S., Vorob'eva O.S. Sub"ekt-predmetnye i ob"ekt-predmetnye otnosheniya v potreblenii // Psikhologiya i psikhotekhnika. 2014. № 10. S. 1021-1032. (DOI: 10.7256/2070-8955.2014.10.12779).

8. Stolin V.V. Samosoznanie lichnosti. M.: Izd-vo MGU, 1983. $286 \mathrm{s.}$

9. Smorkalova T.L., Dotsenko E.L. Mesto Ya-kontseptsii v potrebitel'skikh pred-pochteniyakh: rabochaya model' // Vestnik Tyumenskogo gosudarstvennogo universiteta. 2011. № 9. S. 182-189.

10. Sirgy M.J. Self-concept in consumer behavior - Diss. PhD / Institute: University of Massachusetts Amherst, 1979.120 p.

11. Starcevic S. Self-concept as a significant determinant of brand choice and consumer buying behavior // Marketing. 2001. Vol. 42, No. 2, pp.106-117.

12. Asif Khan M., Bozzo C. Connection between self-concept and brand preference and the role of product usage // International IJAS Conference for Academic Disciplines, 13-16 March 2012, Las Vegas, USA (http://www.cergam.org/fileadmin/files/ cerog/wp/912.pdf).

13. Azar Ofer H. Tipping Motivations and Behavior in the US and Israel // Journal ofApplied Social Psychology. 2014. 40 (2), pp. 421-457. (URL: http://www.nbpublish.com/go_to_article.php?id=31238).

14. Dommer S., Swaminathan V., Ahluwalia R. Using Differentiated Brands to Deflect Exclusion and Protect Inclusion: The Moderating Role of Self-Esteem on Attachment to Differen-tiated Brands // Journal of Consumer Research. 2013.40 (4), pp. 657-675.

15. Villarino R.R., Otero-Lopez J.M. April Lane Benson (ed.): I shop therefore I am: compulsive buying and the search for self; Susanne Friese: Self-concept and identity in a consumer society: aspects of symbolic product meaning // Journal of Consumer Policy. 2001. T. 24. № 3-4, pp. 441-447.

16. Reed A.Ii. Social Identity as a useful perspective for self-concept-based consumer re-search // Psychology \& Marketing. 2002. T. 19. № 3, p. 235. 